2. Биопрепараты в сельском хозяйстве. Методология и практика применения микроорганизмов в растениеводстве и кормопроизводстве / Под ред. И.А. Тихоновича, Ю.В. Круглова. М., 2005. 154 с.

3. KapulnikY. Plant growth promotion by rhizosphere bacteria. Plant Root: the hidden half. Edited by Waisel Y., Eshel A., Kafkafi U. Marcel Dekker Ink. New York, Basel, Hong Kong. 1996. P. 769-780.

4. Муродова С.С., Давранов К.Д. Комплексные микробные препараты. Применение в сельскохозяйственной практике. Biotechnologia Acta. 2014. V. 7, No 6. C. 92-101.

5. Singh R., Kumar M., Mittal A., Kumar M. P. Microbial metabolites in nutrition, healthcare and agriculture. Biotech. 2017. V.7. P. 15. doi.org/10.1007/s13205-016-0586-4

6. Андреюк К.І., Іутинська Г.О., Антипчук А.Ф. Функціонування мікробних ценозів грунту в умовах антропогенного навантаження. К.: Обереги, 2001. 240 с.

7. Курдиш I.К. Інтродукція мікроорганізмів у агроекосистеми. К.: Наукова думка, 2010. 255 с.

DOI https://doi.org/10.30525/978-9934-26-111-4-58

\title{
ВИКОРИСТАННЯ БІОПРЕПАРАТІВ В АГРОЦЕНОЗАХ ЛЬОНУ ОЛІЙНОГО
}

\author{
Шувар А. М. \\ кандидати сільськогосподарських наук, \\ завідувач відділу технологій в рослинництві
}

Інститут сільського господарства Карпатського регіону

Національної академії аграрних наук України

\section{Тимчишин О. Ф.}

кандидати сільськогосподарських наук, стариий науковий співробітник відділу технологій в рослинництві Інститут сільського господарства Карпатського регіону Національної академії аграрних наук України м. Львів, Украӥна

Завдяки своїм унікальним властивостям, особливо екологічній чистоті, попит на продукцію льону олійного й продукти його переробки зростає не тільки на внутрішньому ринку України, а й в провідних промислово розвинутих країнах світу [1]. Враховуючи 
експортну орієнтацію вітчизняного аграрного виробництва, висока ринкова ціна насіння льону визначає його експортний потенціал $\mathrm{i}$ зумовлює його прибутковість, близьку до рівня соняшника. За останніх 20 років Україна сформувала та значно наростила експорт насіння льону олійного, який впродовж 2013-2017 pp. зріс із 10,9 до 56,8 тис. т, а лляної олії - 32,8 до 9,9 тис. т [2].

Дослідженнями наукових установ встановлено, що льон олійний за своїми агробіологічними особливостями пристосований для вирощування в умовах зон Карпатського регіону (Лісостеп, Полісся, Передкарпаття та ін.) на різних типах грунтів і його потенційна продуктивність може сягати 2,0-3,0 т/га [3, 4].

Значним резервом збільшення врожайності та покращення якості продукції льону є вдосконалення базових моделей технологій на основі комплексного застосування засобів біологізації.

Система удобрення в органічній технології вирощування передбачає застосування позакоренево у фазу ялинки різних видів біопрепаратів фунгіцидної та рістстимулювальної дії з доповненням комплексними водорозчинними добривами, збалансованими за вмістом макро-i мікроелементів. Застосування біопрепаратів на різних етапах технології вирощування льону олійного позитивно впливає на ріст і розвиток рослин та якісні показники насіння $[5,6]$.

Дослідження проводили в Інституті сільського господарства Карпатського регіону Національної академії агарних наук України у 2018-2020 pр. на сірому лісовому поверхнево оглеєному грунті 3 низьким забезпеченням азотом, середнім - фосфором і низьким калієм. Застосовували для позакореневого внесення біопрепарати Вітазим (1,0 л/т, 1,0 л/га), Спектрум аскостарт (4,0 л/т), Спектрум аскоріст $(3,0$ л/га), Еколайн бор преміум (1,0 л/га), Еколайн універсал ріст аміно (2,0 л/га), Вимпел-2 (0,5 л/га), Натурвітал всп (1,0 кг/га), Спектрум мікс-с (4,0 кг/га), Гаупсин форте (3 л/га), Актарофіт К» (0,3 л/га), Триховерин (1,5 л/т), Мікоапплай (40 г/т).

Застосування рістстимуляторів і біопестицидів змінило тривалість вегетаційного періоду льону. Зокрема, застосування стимулятора росту Вітазим (1,0 л/т) збільшило тривалість фази ялинки на 4-5 днів, Спектрум аскостарт (4,0 л/т) - 3-4 дні, інших біопрепаратів - на 1-3 дні порівняно до контролю.

Оброблення насіння рістстимуляторами Вітазим i Спектрум аскостарт підвищило польову схожість насіння на 4,5-5,3\%, а біофунгіциду Триховерин - на 1,2% (71,4\% на контролі). 
Найбільший вплив серед досліджуваних рістрегуляторів на розвиток антракнозу проявили Вітазим, Еколайн бор преміум (1,0 л/га), Еколайн універсал ріст аміно (2,0 л/га) та Спектрум аскостарт (4,0 л/т). За їх внесення розвиток хвороби на час настання ранньої жовтої стиглості був у межах 22,0-27,1\% (на контролі $37,2 \%$ ), а технічна ефективність становила 31,3-41,0\%. Серед біопрепаратів найбільше вплинули на розвиток антракнозу Гаупсин форте $(7,0$ л/га) та Триховерин (1,5 л/га). При їх застосуванні поширення антракнозу на початку ранньої жовтої стиглості становило 22,3-22,9\%, технічна ефективність - 38,6-40,2 \%. На контролі розвиток хвороби становив $37,2 \%$. Поширення фузаріозного в'янення перебувало в межах 1,0-4,0 $\%$, а ураженість ним не перевищувала $1 \%$ на всіх варіантах досліду у фазу ранньої жовтої стиглості. Технічна ефективність біоінсектициду Актарофіт К проти блішок на посівах льону (фаза сходів) становила 75,2-84,5\%.

Серед рістстимуляторів найвищу продуктивність насіння льону $(1,34 \mathrm{~T} / г$ а) отримано від використання Вітазим (1,0 л/т). Приріст до контролю - 0,17 т/га (14,1\%). Інші стимулятори зумовили збільшення врожайності насіння в межах 0,11-0,12 т/га (9,5-10,9\%).

Застосування Вітазиму, Еколайн бор і Вимпел-2 підвищило вміст олії в насінні льону на $0,5-0,6 \%$. Найвищий вихід олії льону $(0,563$ т/га) отримано при використанні біостимулятора Вітазим для оброблення насіння перед сівбою $(1,0$ л/т) $-20,3 \%$. Його використання позакоренево у фазу ялинки (1 л/га) збільшило вихід олії на 0,08 т/га $(17,1 \%)$. На контролі - 0,468 т/га.

Отримане насіння льону олійного $є$ екологічно безпечним, вміст важких металів у насінні за застосування комплексних мікродобрив, біопестицидів і рістстимуляторів був нижчим ГДК (вміст цинку - 11,412,7 мг/кг (ГДК - 50 мг/кг), свинцю - 0,01-0,07 мг/кг (ГДК - 0,3 мг/кг), кадмію - не більше 0,010 мг/кг (ГДК - 0,03 мг/кг), міді - 5,9-6,8 мг/кг (ГДК - 10,0 мг/кг).

\section{Література:}

1. Виноградов Д. В., Кунцевич А. А. Влияние норм высева и удобрений на продуктивность льна масличного. Вестник КрасГАУ. 2015. № 6 (105). С. 182-187.

2. Рудік Н. М. Економічний потенціал виробництва льону олійного в Україні. Агросвіт. 2020. № 2. С. 61-68.

3. Дрозд О. М. Технології вирощування льону олійного. Вісник аграрної науки. 2007. № 7. С. 24-26. 
4. Янишевский Л. И., Мацийчук В. М. Экологическая оценка технологии выращивания льна масличного в условиях Полесья. Вестник Белорус. гос. с.-х. акад. 2017. № 3. С. 38-41.

5. Влияние различных систем выращивания, обработки растительных остатков, микроудобрений и бактериальных препаратов на биометрические показатели и урожайность льна масличного / О. А. Коваленко, М. И. Федорчук, М. М. Корхова, В. В. Думич. Agronomie şi Agroecologie : materialele Simpozionului Ştiinţific Internaţional «85 ani ai Facultăţii de Agronomie - realizări şi perspective», dedicat aniversării a 85 de ani de la fondarea Universităţii Agrare de Stat din Moldova. LUCRĂRI ŞTIINŢIFICE. 2018. Vol. 52 (1). P. 47-51. URL: http://dspace.mnau.edu.ua/jspui/handle/123456789/5354.

6. Думич В. Дослідження ефективності застосування біопрепаратів у технології вирощування льону олійного. Техніко-технологічні аспекти розвитку та випробування нової техніки $i$ технологій для сільського господарства Украӥни : зб. наук. пр. УкрНДІПВТ ім. Л. Погорілого. 2019. Вип. 24 (38). С. 296-301 